PHC は他の殺虫剤よりもイエバエに対して効果的であるが， 共力剤の効果は顕著ではなかった。

CPMC は各系統に対し PHC より感受性が低く, 共力刻の 効果は認められなかった。

また, MPMC は各系統に対し，NAC よりも感受性である が, PHC や PMC よりも感受性は低かった。共力剤の効果は 認められたが， 1:10 に混合した場合でも PHC 単独の効果 に及ばなかった。この薬剤においても札幌系の 感受性は高く， malathion 抵抗性とカーバメート系殺虫剂に対する感受性の間 に特異な関係のあることがうかがえる。
GD-11 は pyrethroid 類に対しては顕著な共力作用が認めら れていないが，カーバメート系殺虫戍に対してはかなり効果的 でことに，NAC に著しい共力作用のあることは新しい知見 である。また，NAC や MPMC が系統間に感受性の差異が大 きいことも興味深い点である。

\section{引用交 献}

林 晃史 - 向 暁 - 山口 宏. 田中哲雄 (1972) 防虫科学 $37: 3 \sim 7$.

\section{2-ヒドロキシメチル-5-ヒドロキシー 4-ピリドンの経口投与による 4 眠交 雑種からの 3 眠虫出現についで・2}

村越 重雄·櫟本 五男

神奈川県蟇業センター・大阪府立大学農学部

(1972 年 5 月 29 日受領)

前報（村越，1972）において通常飼育している 4 眠交雑種の 4 齢起亘よりこうじ酸（以下 KA と略す）を経口投与することに よって 3 眠虫が出現することを報告した。さらに 3 眠皇の出現 と化学構造の関係を調べるため 14 種類の KA 関連物質につい て調ベたところ，2-ヒドロキシメチル-5-ヒドロキシ-4-ピリド ンが KA より低濃度において 3 眠龺を出現させることを見い出 したので，その結果について報告する。

本報告を行なうにあたり，研究の遂行に御援助を賜わりまし た東京大学農学部鈴木昭憲助教授 並びに 理化学研究所張清节博 士, 実験に御協力いただいた神奈川県龺業センター富田一郎氏, 田所卜ミエ嬢の各位に対しまして厚くお礼申し上げます。

材料と方法

供試化合物：4-ピロン系化合物として KA〔1〕の他にマルト ール〔2]，アロマルトール〔3]，5-メチル-KA〔4]，6-ヒドロ キシメチルーアロマルトール[5]，2,6-ジメチル-4-ピロン [6]， 6-ヒドロキシメチル-KA〔7〕，5-ベンジル-KA〔8〕，ケリドン 酸〔9]，コメン酸エチルェステル〔10]， $\alpha$-クロル $\mathrm{KA}[11] の$ 10 種，4-ピリドン系化合物として2-ヒドロキシメチル-5-メトキ
シ-4-ピリドン〔12]，2-メチル-3-ヒドロキシー4-ピリドン〔13], 2-ヒドロキシメチル-5-ヒドロキシ-4-ピリドン〔14]の 3 種,他に 3,6-ジヒドロキシメチル-1,4-ジヒドロピリダジン〔15]の合計 15 種類を用いたが，これらの化合物は著者の一人櫟本らの合成 したものである (IснIмото et al., 1965, 1966, 1967; 櫟本, 1970)。各化合物の構造を第 1 表に示した。

第 1 表 供試化合物の構造

\begin{tabular}{|c|c|c|c|c|c|}
\hline \multirow{2}{*}{$\begin{array}{l}\text { 供 試 } \\
\text { 化合物 }\end{array}$} & \multicolumn{2}{|c|}{ 置 } & \multicolumn{2}{|c|}{ 換 基 } & \multirow{2}{*}{ 基本骨格 } \\
\hline & $\mathrm{R}_{2}$ & $\mathrm{R}_{3}$ & $\mathrm{R}_{5}$ & $\mathrm{R}_{6}$ & \\
\hline$[1]$ & $\mathrm{CH}_{2} \mathrm{OH}$ & $\mathrm{H}$ & $\mathrm{OH}$ & $\mathrm{H}$ & \\
\hline$[2]$ & $\mathrm{CH}_{3}$ & $\mathrm{OH}$ & $\mathrm{H}$ & $\mathrm{H}$ & \\
\hline [3] & $\mathrm{CH}_{3}$ & $\mathrm{H}$ & $\mathrm{OH}$ & $\mathrm{H}$ & \\
\hline$[4]$ & $\mathrm{CH}_{2} \mathrm{OH}$ & $\mathrm{I} \mathrm{H}$ & $\mathrm{OCH}_{3}$ & $\mathrm{H}$ & \\
\hline$[5]$ & $\mathrm{CH}_{3}$ & $\mathrm{H}$ & $\mathrm{OH}$ & $\mathrm{CH}_{2} \mathrm{OH}$ & \\
\hline$[6]$ & $\mathrm{CH}_{3}$ & $\mathrm{H}$ & $\mathrm{H}$ & $\mathrm{CH}_{3}$ & \\
\hline$[7]$ & $\mathrm{CH}_{2} \mathrm{OH}$ & $\mathrm{H}$ & $\mathrm{OH}$ & $\mathrm{CH}_{2} \mathrm{OH}$ & \\
\hline$[8]$ & $\mathrm{CH}_{2} \mathrm{OH}$ & $\mathrm{H} \mathrm{OC}$ & $\mathrm{CH}_{2} \mathrm{C}_{6} \mathrm{H}$ & $\mathrm{H}_{5} \quad \mathrm{H}$ & \\
\hline$[9]$ & $\mathrm{COOH}$ & $\mathrm{H}$ & $\mathrm{H}$ & $\mathrm{COOH}$ & \\
\hline$[10]$ & $\mathrm{COOC}_{2} \mathrm{H}_{5}$ & ${ }_{5} \mathrm{H}$ & $\mathrm{OH}$ & $\mathrm{H}$ & \\
\hline 〔11] & $\mathrm{CH}_{2} \mathrm{Cl}$ & $\mathrm{H}$ & $\mathrm{OH}$ & $\mathrm{H}$ & \\
\hline$[12]$ & $\mathrm{CH}_{2} \mathrm{OH}$ & $\mathrm{I} \mathrm{H}$ & $\mathrm{OCH}_{3}$ & $\mathrm{H}$ & \\
\hline 〔13] & $\mathrm{CH}_{3}$ & $\mathrm{OH}$ & $\mathrm{H}$ & $\mathrm{H}$ & \\
\hline$[14]$ & $\mathrm{CH}_{2} \mathrm{OH}$ & $\mathrm{H} \mathrm{H}$ & $\mathrm{OH}$ & $\mathrm{H}$ & $\mathrm{H}$ \\
\hline 〔15] & $-\mathrm{C}$ & $\mathrm{CH}_{2} \mathrm{OH}$ & $\mathrm{H}$ & $\mathrm{CH}_{2} \mathrm{OH}$ & $\underbrace{\mathrm{N}}_{\mathrm{H}}$ \\
\hline
\end{tabular}

1 On the appearance of three-moulters from the $\mathrm{F}_{1}$-hybrid of four-moulters in the silkworm, Bombyx mori L., due to oral administration of a 2-hydroxymethyl-5-hydroxy-4-pyridone. By Shigeo MURAKoshI (Kanagawa Prefectural Institute for Sericultural Science, Ebina-shi, 243), Itsuo Icнімото (Department of Agricultural Chemistry, College of Agriculture, University of Osaka Prefecture, Sakai, 591)

2 本報告の一部は昭和 47 年度応動昆大会において発表した。 日本応用動物昆虫学会誌（応動昆）第 16 巻 第 3 号 : 159〜161（1972） 
カイコ幼虫に対する経口投与：カイコの品種は 4 眠交雑種で ある $8.3 \times 3.4$ と春嶺 $\times$ 鐘月を用いた。 1 齢期の飼育と 4 齢 起虫よりの実験には前報（村越, 1972）の人工飼料を用いた。1 〜 3 龄期の飼育は $27 \sim 30^{\circ} \mathrm{C}$ で無菌飼育した。各化合物は主と して温水に溶解して飼料に混入したが，5-ベンジル KA のみは エタノールに溶解して飼料に混入した後エタノールを除去した。 なお，濃度は加水後の人工飼料中に含まれる量で示した。まず， 各化合物の $1.0 \%$ 含有鸰料を 4 齢起龺各区共 5 頭に連続投与し た。この濃度で影響のあった化合物についてはさらに $0.2 \%$, $0.1 \%$ で調べた。2-メチル-3-ヒドロキシ-4-ピリドン〔13〕と 2-ヒドロキシメチル-5-ヒドロキシ-4-ピリドン〔14】は $0.1 \%$ 以下についても検討した。〔14〕は最も活性が高かったので, 経 口投与量を算出するために近似食下量を調査した。4 齢幼虫の 飼育は $25^{\circ} \mathrm{C}$ でシャーレー育とし, 飼料は $1 \sim 3$ 日に 1 度交換 した。

\section{結果と考察}

供試化合物 $1 \%$ 含有飼料を 4 齢起奛より連続投与した結果を 第 2 表に示す。

第 2 表に示したように成育に対する影響は 3 つのグループに 別れた。第 1 のグループは 4 齢飼育中に死亡したものが多かっ た化合物で，〔2]，〔3]，〔6]，〔7〕，〔8]，〔11]，〔12〕，〔13〕， 〔14]の 9 種が含まれる。第 2 のグループは 3 眠亘出現の多かっ た化合物で [1]，〔4]，〔5〕の 3 種が含まれる。このグループは $-\mathrm{CH}_{2} \mathrm{OH}$ 基をいずれも持っている。第 3 のグループは影響の 見られなかった化合物で側鎖に $-\mathrm{COOH}$ および $-\mathrm{COOC}_{2} \mathrm{H}_{5}$ を有する〔9]，〔10〕とピリダジン系化合物〔15〕である。

以上の結果より，さらに，第 3 のグループを除いた化合物に ついて $0.2 \%$ 含有飼料を春嶺 $\times$ 鐘月の 4 䶘起虫より各区共 5 頭 に連続投与した。

その結果，〔13〕と〔14】は 4 令 3 日後までに死亡した。〔8】 と〔11〕恃成育が非常に劣った。他の化合物，〔1]，〔2〕，〔3]， [4]，〔5]，〔6]，〔7〕，〔12〕は7 日後までにすべて5 齢になりほ とえど影響は見られなかった。〔1]，〔4]，〔5]，〔12〕はいずれ
第 2 表 カイコ 4 齢幼虫に対する各化合物の影響*

\begin{tabular}{|c|c|c|c|c|c|}
\hline \multirow{2}{*}{$\begin{array}{l}\text { 供 試 } \\
\text { 化合物 }\end{array}$} & & 日後の成育 & \multirow{2}{*}{$\begin{array}{l}4 \text { 齢飼育中 } \\
\text { 死 }\end{array}$} & \multicolumn{2}{|c|}{ 上 蔟 数 } \\
\hline & \multicolumn{2}{|c|}{ 生存数 ( 5 歯令 -4 眠- 4 歯令) } & & 4 齢 & 5 歯令 \\
\hline 無添加 & 5 頭 & $(5-0-0)$ & 0 頭 & 0 頭 & 5 頭 \\
\hline$[1]$ & 5 & $(0-0-5)$ & 2 & 3 & 0 \\
\hline$[2]$ & 0 & - & 5 & & \\
\hline [3] & 0 & $\longrightarrow$ & 5 & & - \\
\hline$[4]$ & 5 & $(0-1-4)$ & 0 & 3 & 2 \\
\hline$[5]$ & 5 & $(0-0-5)$ & 0 & 5 & 0 \\
\hline$[6]$ & 0 & - & 5 & & \\
\hline$[7]$ & 4 & $(0-0-4)$ & 5 & & \\
\hline$[8]$ & 0 & $\longrightarrow$ & 5 & & - \\
\hline$[9]$ & 5 & $(5-0-0)$ & 0 & 0 & 5 \\
\hline$[10]$ & 5 & $(4-1-0)$ & 0 & 0 & 5 \\
\hline 〔11〕 & 0 & - & 5 & & - \\
\hline [12] & 5 & $(0-0-5)$ & 4 & 1 & 0 \\
\hline$[13]$ & 0 & $\longrightarrow$ & 5 & & \\
\hline 〔14] & 0 & $\overline{-}$ & 5 & - & - \\
\hline 〔15] & 5 & $(2-3-0)$ & 0 & 0 & 5 \\
\hline
\end{tabular}

* 供試化合物の飼料中濃度は $1.0 \%$.

も 3 眠虫の出現が見られなかったので，0.5\% 含有飼料による 影響を調べたところ，〔1]，〔5]，〔12〕は若干の 3 眠奛が出現し

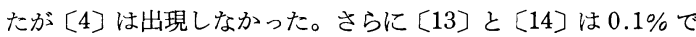
テストしたところ，4 齢 3 日後までに全て死亡した。この $2 つ$ の化合物についてはより低濃度においての影響を検討した。す なわち, 春嶺 $\times$ 鐘月の 4 齢起虫 1 区 10 頭に両化合物の 100 , $200,400,800 \mathrm{ppm}$ を連続投与した。その結果を第 3 表に示す。

表より明らかなように〔13〕は $400 \mathrm{ppm}$ 以上,〔14〕は 200 ppm 以上ですべて死亡した。〔13〕の $100 \mathrm{ppm}$ はほとえど影 響が見られなかったが， $200 \mathrm{ppm}$ では最終的に 3 頭の 3 眠龺が 出現した。化合物〔14〕については $100 \mathrm{ppm}$ で 3 眠虫の出現を 起こすことがわかったが (10 頭中 2 頭の 3 眠虫が出現した), $200 \mathrm{ppm}$ では死亡してしまったので，4 齢 3 日後まで 200 ppm を投与し, 以後は無添加飼料を与えて, 前報（村越，1972）の KA の場合と同様に 3 肵虫が出現するかどうか調べたととろ，

第 3 表 2 -メチル-3-ヒドロキシ-4-ピリドンと 2-ヒドロキシメチル-5-ヒドロキシ-4-ビリドンの 経口投与によるカイコ 4 齢幼虫に対する影響

\begin{tabular}{|c|c|c|c|c|c|c|c|c|c|c|c|c|c|c|c|}
\hline \multirow{2}{*}{$\begin{array}{l}\text { 供 試 } \\
\text { 化合物 }\end{array}$} & \multirow{2}{*}{$\begin{array}{c}\text { 濃 度 } \\
(\mathrm{ppm})\end{array}$} & \multicolumn{2}{|r|}{ 平 } & \multirow{2}{*}{$\frac{\text { 均 }}{2}$} & \multirow{2}{*}{$\frac{\text { 生 }}{3}$} & \multirow{2}{*}{$\frac{\text { 体 }}{4}$} & \multicolumn{3}{|c|}{ 重*（mg） } & \multicolumn{2}{|r|}{ 累 } & 積 死 & 亡 & \multicolumn{2}{|c|}{ 率 $(\%)$} \\
\hline & & 0 日 & 1 & & & & 5 & 6 & 7 & 2 日 & 3 & 4 & 5 & 6 & 7 \\
\hline 無添加 & 一 & 145 & 251 & 410 & 600 & 715 & 798 & 958 & 1,431 & 0 & 0 & 0 & 0 & 0 & 0 \\
\hline \multirow{4}{*}[13]{} & 100 & 128 & 222 & 346 & 472 & 693 & 793 & 826 & 995 & 0 & 0 & 0 & 0 & 0 & 0 \\
\hline & 200 & 130 & 216 & 303 & 386 & 496 & 607 & 703 & 804 & 0 & 0 & 0 & 0 & 0 & 0 \\
\hline & 400 & 132 & 189 & 235 & 264 & 288 & 311 & - & - & 0 & 0 & 0 & 70 & 100 & - \\
\hline & 800 & 136 & 187 & 199 & 206 & - & - & - & 一 & 0 & 70 & 100 & - & - & - \\
\hline \multirow{4}{*}[14]{} & 100 & 127 & 215 & 301 & 378 & 470 & 557 & 639 & 703 & 0 & 0 & 0 & 0 & 0 & 0 \\
\hline & 200 & 130 & 216 & 253 & 272 & 289 & 300 & - & - & 0 & 0 & 30 & 80 & 100 & - \\
\hline & 400 & 131 & 198 & 239 & 257 & 266 & - & - & - & 0 & 10 & 40 & 100 & - & - \\
\hline & 800 & 141 & 199 & 205 & - & - & - & - & - & 0 & 100 & - & - & - & - \\
\hline
\end{tabular}

* 生体重は生存蚕の平均で示した. 
第 4 表 2-ヒドロキシメチル-5-ヒドロキシ-4-ピリドン〔14〕の経口投与量と 3 肵龺出現との関係*

\begin{tabular}{|c|c|c|c|c|c|c|c|}
\hline \multirow{2}{*}{$\begin{array}{l}\text { 飼料中 } \\
\text { 濃 度 }\end{array}$} & \multirow{2}{*}{$\begin{array}{l}\text { 起 䖺 } \\
\text { 生体重 }\end{array}$} & \multirow{2}{*}{$\begin{array}{l}3 \text { 日後 } \\
\text { 平均 } \\
\text { 生体重 }\end{array}$} & \multirow{2}{*}{$\begin{array}{l}3 \text { 眠蚕 } \\
\text { 出現数 }\end{array}$} & \multicolumn{4}{|c|}{4 齢 0 〜 3 日後における（1頭当り平均） } \\
\hline & & & & 生 給物一飭 ${ }^{\text {量 }}$ 物 & $\begin{array}{l}\text { 食 下量 } \\
\text { 物-乾 }\end{array}$ & 食下率 & $\begin{array}{l}\text { 〔14〕の } \\
\text { 食下量 }\end{array}$ \\
\hline $0 \mathrm{ppm}$ & $164 \mathrm{mg}$ & $678 \mathrm{mg}$ & 0 頭 & $1,400 \mathrm{mg}-368 \mathrm{mg}$ & $1,229 \mathrm{mg}-323 \mathrm{mg}$ & $87.8 \%$ & $0 \mu \mathrm{g}$ \\
\hline 100 & 162 & 650 & 1 & $1,400-368$ & $1,124-296$ & 80.3 & 112.4 \\
\hline 200 & 161 & 576 & 9 & 1,400 & -240 & 65.1 & 182.3 \\
\hline
\end{tabular}

* 春嶺 $\times$ 鐘月の 4 齢起㔬 1 区 10 頭, $25^{\circ} \mathrm{C}$, シャーレー育.

〔14】の $100 \mathrm{ppm}$ と $200 \mathrm{ppm}$ 含有飼料は 4 齢起虫より 3 日後まで与え, それ以後は無添加飼料を与えた.

10 頭中 8 頭が 3 眠虫となって, 同じく 4 齢の前半期投与により 3 呡虫が出現した。

よって，〔14〕の経口投与量と 3 眠虫出現との関係を調べるた めに, 春嶺 $\times$ 鐘月の 4 齢起寔 10 頭に $100 \mathrm{ppm}$ と $200 \mathrm{ppm}$ を 3 日間連続投与し, 近似食下量より経口投与量を算出した。そ の結果を第 4 表に示す。

〔14】の $100 \mathrm{ppm}$ では 1 頭, $200 \mathrm{ppm}$ では 9 頭の 3 眠虫が出 現した。さらに, 食下率より換算した 1 頭当り〔14〕の食下量 (経口投与量) は $100 \mathrm{ppm}$ の場合が $112.4 \mu \mathrm{g}, 200 \mathrm{ppm}$ の場 合が $182.3 \mu \mathrm{g}$ となり 3 眠虫の出現は経口投与量と正の相関を 示した。別に KA の経口投与量と 3 眠虫の出現との関係を調べ たところ, KA $1 \%$ 含有飼料を 4 歯令 3 日後まで与えた場合に 3 眠虫の出現は 10 頭中 3 頭で 1 頭当り KA は $6.4 \mathrm{mg}, \mathrm{KA} 1$ $\%$ 含有飼料を 4 歯令中与えた場合に 3 眠蚕の出現は 10 頭中 8 頭で 1 頭当り KA は $22.6 \mathrm{mg}$ 食下された。したがって, ほとんど の 4 歯令を 3 肵亘化するに要する 1 頭当り経口投与量を KA 20 $\mathrm{mg}$, [14】 $200 \mu \mathrm{g}$ とすると〔14】の 2-ヒドロキシメチル-5-ヒ ドロキシー4-ビリドンは KA の 100 倍の活性を示したことにな る。

$\mathrm{KA}$ 〔 $14 〕 の$ 構造的相違は KA が 4-ピロン骨格であるのに 対して〔14】が 4-ピリドン骨格であることで,このような化学構 造の相違は〔2〕と〔13】，44〕と〔12〕においてもあてはまる。 したがって, 基本骨格および置換基の相違とカイコ幼虫成育に
対する影響との間には興味ある関係が見られた。

3 眠虫がいかなる生理機構により出現するのかは物質代謝レ ベルでは明白にされていない。しかしながら，実験形態学的に は 4 齢の $2 / 3$ 経過時までにアラタ体を摘出することによって, 3 眠毛が出現することは良く知られている（金，1939）。このこ とから，KA および 2-ヒドロキシメチル-5-ヒドロキシ-4-ピ リドン等の化学物質を 4 齢前半期に一定量以上 経口投与した場 合にアラタ体摘出と結果的には同様な現象が現われ 3 眠虫化す るのかも知れない。さらに, これらの化学物質がいかなる作用 機構で 3 眠虫の出現に関与しているかは今後の検討に待たれる 問題である。

引用交献

Iснімото, I., K. Fujil and C. Tatsumi (1965) Agr. biol. Chem. $29: 325 \sim 330$.

Iснімото, I., K. Fujil and C. Tatsumi (1967) Agr. biol. Chem. 31:979 989.

Iснімото, I., Y. KiтAOKA and C. TATsumi (1966) Tetrahedron $22: 841 \sim 846$.

櫟本五男 (1970) 大阪府立大学紀要 農学・生物学 $22: 209$. 金 順鳳（1939）日亘雑 $10: 86 \sim 97$.

村越重雄 (1972) 応動昆 $16: 111 \sim 113$.

\section{ブニョール教授講演会のこ案内}

仏国ボルドー大学の J. J. BounioL 教授は，日仏農学会の招聘により，仏国政府交化使節として 9 月27日来日 されることになりました。

教授が動物学者として，また昆虫内分泌学研究の先駆者として令名の高いことは，ここにご紹介するまでもあ りますまい。教授は約 1 か月日本に滞在し, 各地で講演を行なうことになっていますが，東京では日仏農学会， 日本応用動物昆虫学会, 日本虫系学会などの共催で次のような講演会が開かれます。会員諸氏の多数ご参会をお 待ち申しております。

日 時: 10 月 16 日（月）午後 6 時半

場 所: 日仏会館講堂（神田駿河台）

演 題: 脊椎動物の生物学（通訳つき） 